\title{
TUEN MERKITYKSENTYMINEN POTILAS-HOITAJASUHTEESSA OSASTOHOIDOSSA
}

\begin{abstract}
LECTIO PRAECURSORIA PUHEVIESTINNÄN VÄITÖSKIRJAN "TUEN MERKITYKSET POTILAAN JA HOITAJAN VUOROVAIKUTUKSESSA" TARKASTUSTILAISUUDESSA JTVÄSKYLÄN YLIOPISTOSSA 16.12.2006. VASTAVÄITTÄJÄNÄ TILAISUUDESSA OLI DOSENTTI ELINA ERIKSSON (TURUN YLIOPISTO) JA KUSTOKSENA PROFESSORI MAARIT VALO.
\end{abstract}

\section{Leena Mikkola, FT}

Viestintätieteiden laitos, byuäskylän yliopisto

Vuorovaikutusta voi pitää ihmisenä olemisen perustana. Se tekee meistä sen, mitä olemme. Vuorovaikutuksessa muiden kanssa yksilö rakentaa kuvaa omasta minästään, luo ihmissuhteita ja ylläpitää yhteisöjä ja kulttuuria. Puheviestintätiede pyrkii ymmärtämään ihmisen ajattelua ja toimintaa siitä näkökulmasta, millä tavoin vaikutamme toinen toisiimme ja millä tavoin olemme kanssakäymisessä toistemme kanssa. Inhimillisenä ilmiönä vuorovaikutus antaa mahdollisuuden hyvään ja pahaan. Sanoilla ja sanattomalla viestinnällä voimme loukata, mutta myös paikata, korjata ja rakentaa. Minua tutkijana kiinnostaa erityisesti se, millä tavoin vuorovaikutuksessa syntyy hyväksi ja positiiviseksi koettuja seurauksia ja millä tavoin vuorovaikutus voisi lisätä hyvinvointiamme. Minua kiinnostaa myös se, miksi hyvät aikomuksemme eivät aina toteudu. Miksi joskus pyrkimyksemme auttaa tulee ymmärretyksi väärin tai aiheuttaakin mielipahaa? Näihin kysymyksiin olen etsinyt vastausta tarkastelemalla vuorovaikutusta sosiaalisen tuen ilmiön ja tuelle annettujen merkitysten kautta.

Sosiaalinen tuki on monitahoinen ilmiö tai prosessi, joka kytkee yksilön hyvinvoinnin yksilön viestintäsuhteisïn. Sosiaalisen tuen käsitteellä viitataan yleensä kolmeen tekijään. Ensinnäkin tuki kuvaa yksilön 
ja hänen sosiaalisen ympäristönsä välisiä kiinnikkeitä, liittymistä, joka kehkeytyy vuorovaikutuksessa. Toiseksi tuki viittaa vuorovaikutuksessa syntyviin ja yksilölle välittyviin resursseihin, jotka edistävät hyvinvointia. Kolmanneksi tuen käsitteellä tarkoitetaan sitä viestintää, jossa tuki syntyy ja jossa sitä välittyy, jossa tukea annetaan ja saadaan. Tätä prosessia voidaan kutsua myös supportiivisen eli tukea antavan viestinnän käsitteellä.

Puheviestinnän alalla sosiaalinen tuki on nähty funktionaalisena, eli tiettyä tehtävää ja tavoitetta kantavana verbaalisena ja nonverbaalisena viestintänä, joka vahvistaa yksilön käsitystä elämänhallinnasta. Tämä tapahtuu siten, että tuki auttaa hallitsemaan epävarmuutta. Epävarmuus voi liittyä ongelmalliseen tai kuormittavaan tilanteeseen, ja se voi liittyä myös omaan itseen tai vuorovaikutuskumppaniin. Varhaiset näkemykset sosiaalisesta tuesta korostivat sitä, että tuessa on paljolti kyse myös hyväksynnän kokemisesta. Nähdäkseni käsitys hyväksytyksi tulemisesta on edelleen merkityksellinen tekijä tukea tarkasteltaessa.

Sosiaalisella tuella on kiistatta vaikutuksia hyvinvointiin: se näyttää vähentävän sairastumisriskiä ja edistävän paranemista. Se on myös tärkeä selviytymistä edistävä tekijä ongelma- ja kriisitilanteissa. Sairastamista ja sairaalahoitoa voi pitää yksilön elämässä sellaisena kuormittavana tilanteena, jossa kyky selviytyä erilaisista tilanteen tuomista haasteista joutuu koetukselle. Sairaalajakso ajoittuu yleensä sairauden akuuttiin tai kriittiseen vaiheeseen, jolloin yksilön tuen tarve on erityisen suuri. Sairaalaan joutuminen hankaloittaa monien käytännön asioiden hoitamista, ja usein se vaikeuttaa myös potilaan mahdollisuuksia ylläpitää omia vuorovaikutussuhteitaan totutulla tavalla, joten sairaalahoidossa hoitohenkilökunta on tärkeässä asemassa potilaan selviytymisen tukemisessa ja jatkuvuuden turvaamisessa. Erityisesti sairaanhoitajilla on tärkeä rooli tuen antamisessa potilaalle, koska potilaat ovat osastohoidon aikana eniten tekemisissä juuri hoitajien kanssa. Hoitajien tehtäviin kuuluu myös paljon sellaista ohjausta, jonka tavoitteena on välittää tukea. 
Sosiaalisen tuen näkökulmasta sairaalahoidossa välittyvä tuki on kiinnostava ilmiö paitsi lisääntyneen tuen tarpeen vuoksi, myös siksi, että kyse on ammatillisesta auttamissuhteesta. Puheviestinnässä sosiaalista tukea on tarkasteltu paljon läheisissä vuorovaikutussuhteissa ja työyhteisöjen kollegiaalisissa suhteissa, sen sijaan ammatillisia vuorovaikutussuhteita on tarkasteltu vähemmän. Ammatillisessa auttamissuhteessa toisella osapuolella on velvoite tuen osoittamiseen. Se ei kuitenkaan automaattisesti takaa sitä, että viestintä tässä suhteessa olisi supportiivista ja että tukea koettaisiin saatavan.

Aikaisemmissa tutkimuksissa, joissa on verrattu tuen antajan ja tuen saajan käsityksiä sairaalahoidon aikana välittyneestä tuesta, on näiden käsitysten todettu olevan ristiriitaisia. Potilaat ja heidän omaisensa ovat arvioineet heille osoitetun tuen vähäisemmäksi kuin hoitajat arvioivat antamansa tuen. Hoitajat, potilaat ja omaiset näyttäisivät arvioivan eri tavoin myös tuen tarvetta, erityisesti emotionaalisen tuen tarvetta. Tämän on selitetty johtuvan hoitoympäristöstä ja sairaalaorganisaatioon liittyvistä tekijöistä, tuen ajoittamisesta, hoitajien vuorovaikutustaidoista ja siitä, että potilaat ja hoitajat ymmärtävät tuella mahdollisesti eri asiaa.

Oman tutkimukseni tarkoituksena on ollut kuvata ja ymmärtää sosiaalista tukea potilaan ja hoitajan vuorovaikutuksessa osastohoidossa. Tutkimuksen päätavoitteena oli kuvata potilaan ja hoitajan tuelle antamia merkityksiä ja ymmärtää potilas-hoitajasuhdetta tuen perustana. Pyrin myös kuvaamaan ja ymmärtämään sitä, millaisen kontekstin osastohoito luo tuen hakemiselle, osoittamiselle ja saamiselle. Tutkimus perustui laadulliseen menetelmään, ja se toteutettiin erään sairaalan kirurgisella osastolla, jossa havainnoin ja ääninauhoitin potilaan ja hoitajan vuorovaikutusta sekä haastattelin niin potilaita kuin hoitajiakin. Havainnoinnin tarkoituksena oli pystyä kuvaamaan niitä tekijöitä, jotka säätelevät potilaan ja hoitajan välistä viestintää. Haastatteluiden tarkoituksena oli kuvata, miten potilaat ja hoitajat kokevat osastohoidon kontekstin, millainen käsitys heillä on potilas-hoitajavuorovaikutuksesta ja 
millaisia merkityksiä he antavat tuelle. Analysoin aineistoa soveltamalla havaintoaineistoon vuorovaikutusprosessin analyysiä, $j$ a haastatteluiden analyysi perustui laadulliseen sisällön analyysïn.

Tämän tutkimuksen aineistossa potilaana olemisen kokemus rakentui kolmesta ulottuvuudesta: hoidon saamisen kokemisesta, hoitoympäristön kokemisesta ja sairaalan vuorovaikutuskäytänteiden kokemisesta. Näiden ulottuvuuksien voi ajatella kuvastavan sitä, että potilaana olemista säätelee sairaalan institutionaalinen luonne. Hoitajat kuvasivat omaa hoitajuuttaan tiedon hallinnan, prosessien hallinnan ja emotionaalisen hallinnan kautta. Hoitajien tavassa kertoa omasta hoitajuudestaan korostuu luonnollisesti ammatillisuus, koska he kuvaavat rooliaan työyhteisössä ja -ympäristössä. Sekä potilaan että hoitajan kokemusta osastohoidosta selittävät havaintoaineiston tulokset, jotka kuvasivat potilas-hoitajavuorovaikutuksen luonnetta.

Erityisesti aika ja paikka ovat merkityksellisiä ja myös ongelmallisia tekijöitä potilas-hoitajavuorovaikutuksessa, kuten useissa aikaisemmissakin tutkimuksissa on todettu. Tätä tutkimusta varten potilashuoneesta nauhoitettujen vuorovaikutustilanteiden keskimääräinen kesto oli alle neljä minuuttia, lyhyimmät kohtaamiset kestivät vain muutamia kymmeniä sekunteja. Tyypillistä oli myös se, että keskustelut keskeytyvät hyvin usein. Vuorovaikutusta voikin kuvata hyvin sirpaleiseksi. Sairaalan vuodeosastolla on myös vaikea löytää sellaista rauhallista paikkaa, jossa olisi mahdollisuus keskeytymättömään ja yksityiseen keskusteluun. Riittävän ajan ja rauhallisen paikan löytäminen vaikuttavat mahdollisuuksiin hakea ja osoittaa tukea. Potilaan tuen tarpeen näkökulmasta hoitoympäristöön ja hoidon käytänteisiin liittyy tekijöitä, jotka usein itsessään lisäävät kuormitusta ja siten myös tuen tarvetta.

Potilas-hoitajavuorovaikutuksella on useita sisällöllisiä funktioita kuten oireista ja voinnista puhuminen, toimenpiteen ohjaus, hoidosta puhuminen, konkreettisten ongelmien ratkaiseminen, faattinen viestintä sekä tunteiden ilmaiseminen ja tunteista puhuminen. Erityisen 
merkityksellisenä hoitajat ja potilaat pitivät faattista viestintää, eli jokapäiväisistä keskustelunaiheista kuten säästä, televisio-ohjelmista ja ajankohtaisista asioista puhumista. Tämäntyyppisen keskustelun katsottiin palvelevan paitsi viihtymistä ja ajankulkua, myös sairauden unohtamista hetkeksi. Tärkein merkitys sillä näyttäisi olevan kuitenkin hoitajan ja potilaan vuorovaikutussuhteen rakentumiselle.

Kuvatessaan potilas-hoitajavuorovaikutusta niin potilaat kuin hoitajat korostivat relationaalisen viestinnän merkitystä. Tarkoitan relationaalisella viestinnällä nüiä sanomia ja sitä viestintäkäyttäytymistä, jonka perusteella teemme tulkintoja toisen osapuolen suhtautumisesta itseemme. Potilaiden kokemusten perusteella hoitosuhteessa olennaisia tekijöitä ovat aloitteellisuus, josta potilaat tekivät päätelmiä hoitajan halukkuudesta vuorovaikutukseen, sekä henkilökohtaisuus, ymmärretyksi tuleminen ja oikeudenmukaisuus, millä tarkoitetaan potilaiden keskinäistä tasavertaisuutta ja reilua kohtelua. Hoitajat puolestaan kuvaavat hoitosuhdetta sen tavoitteellisuuden, turvallisuuden, henkilökohtaisuuden ja tasavertaisuuden näkökulmasta. Künnostavaa on ennen muuta se, että hoitajat korostavat potilaan ja hoitajan välistä tasavertaisuutta, potilaat puolestaan potilaiden keskinäistä tasavertaisuutta suhteessa hoitavaan henkilökuntaan.

Potilaiden ja hoitajien tuelle antamat merkitykset ovat hyvin samankaltaisia. Tukena pidetään merkityksellistä tietoa, tunteiden oikeuttamista ja käsittelemistä, jatkuvuuden ylläpitämistä sekä vuorovaikutussuhteen olemassaoloa. Hoitajat korostivat myös konkreettisen avun merkitystä. Tuelle annetut merkitykset ovat sen kaltaisia, että niiden voidaan ajatella ylipäätään edustavan merkityksiä, joita suomalaisessa viestintäkulttuurissa tuelle annetaan. Kiinnostavaa näissä merkityksissä on se, että vuorovaikutussuhde itsessään näyttää merkitykselliseltä myös ammatillisessa auttamissuhteessa. Aikaisemmissa tutkimuksissa suhteen ja tuen yhteyttä on korostettu ennen muuta läheisissä suhteissa. Mielenkiintoista on myös se, että merkityksissä korostuu hyväksytyksi 
tuleminen, joka liittyy niin tunteiden oikeuttamiseen kuin vuorovaikutussuhteeseen. Tämä kertoo, että käsitystä hyväksytyksi tulemisesta voidaan todella pitää toisena tuen perustehtävistä elämänhallinnan käsityksen rinnalla ja että käsitys hyväksytyksi tulemisesta on perusteltua nostaa esille myös sosiaalista tukea määriteltäessä.

Erittäin kiinnostavana pidän sitä, että potilaat ja hoitajat antoivat samanlaisia merkityksiä tuelle ja hyvälle hoitosuhteelle. Tämä kertoo käsittääkseni siitä, että voi joskus olla vaikeaa erottaa, milloin omassa kokemuksessa kyse on tuesta ja milloin vuorovaikutussuhteen piirteistä itsessään. Jos näin on, esimerkiksi potilaan kuvaama tyytyväisyys tukeen voikin tarkoittaa tyytyväisyyttä hoitosuhteeseen tai päinvastoin. Sosiaalisen tuen ja vuorovaikutussuhteen keskinäisiä yhteyksiä pitäisi tarkastella lähemmin. Oma tutkimukseni nostaa tässä kohdin enemmän kysymyksiä kuin tuottaa vastauksia: Ensinnäkin on tärkeää kysyä, millaista vuorovaikutussuhdetta tuen toteutuminen edellyttää juuri ammatillisessa yhteydessä. Toiseksi tulisi tarkemmin pohtia, milloin vuorovaikutussuhde on tuen toteutumisen konteksti ja milloin se on tukea itsessään. Kolmanneksi tulisi pohtia viestintäkäyttäytymisen yhteyttä tuen kokemiseen ja supportiivisen vuorovaikutussuhteen syntymiseen.

Vaikka tuelle annetut merkitykset olivat hyvin yhdenmukaisia, hoitajien tavassa kuvata antamaansa tukea tuki hahmottui ensisijaisesti siitä näkökulmasta, kuinka aloitteellista tai responsiivista heidän viestintänsä on. Tuelle annetut merkitykset jäsentyvät süs aloitteelliseksi eteenpäin orientoimiseksi tai responsiiviseksi toisen viestintään reagoimiseksi ja vastaamiseksi. Potilaiden tapa antaa merkityksiä tuelle jäsentyi puolestaan siten, kokivatko he hoitajan toimivan yhdessä potilaan kanssa vai kokivatko he hoitajan olevan potilasta varten. Kanssa olemiseen liittyi merkityksiä aktiivisesta ongelmanratkaisusta ja tunteiden käsittelemisestä, kun taas varten olemiseen liittyi merkityksiä siitä, että toinen pitää huolta jaksamisesta ja kantaa vaikeita asioita tilanteessa, jossa siihen ei itse pysty. Kïnnostavaa oli se, että kuvatessaan itseään tuen saajana hoi- 
tajat merkityksensivät tukea tästä jälkimmäisestä näkökulmasta.

Tutkimuksen tulosten perusteella voi päätellä, että tuen antajan ja tuen saajan rooli jäsentävät tapaa tulkita viestintätilanteessa välittynyttä tukea. Hyvänä esimerkkinä tästä voi pitää niin sanottua konkreettista tukea. Kun tuen antaja tekee jotain konkreettista, auttaa pesulle tai tuo puhtaat vaatteet, on se tuen antajalle itselleen teko. Hän pyrkii vastaamaan toisen tuen tarpeeseen toimimalla. Tuen saajalle tämä teko ei kuitenkaan ole vain teko, koska tuen saaja antaa teolle merkityksen. Merkitys voi olla supportiivinen: merkitys siitä, että toinen osapuoli välittää omasta itsestä. Tällöin teko merkityksentyy hyväksynnän ja huolenpidon ilmaukseksi. Toisaalta on mahdollista, että auttaminen saa myös päinvastaisia merkityksiä. Tukea tarvitsevalle se voi merkitä ja korostaa esimerkiksi omaa kyvyttömyyttä ja pystymättömyyttä.

Potilaiden ja hoitajien tuelle antamat merkitykset eivät siis sinänsä vaikuta kovin erilaisilta, eivätkä ne sellaisenaan selitä tuen antajan ja saajan käsityseroja. Sen sijaan tuen antajan ja tuen saajan roolit voivat näitä käsityseroja selittää. Tukea on kuvattu aiemmin monentyyppisten luokittelujen avulla, jotka perustuvat tukea antavan käyttäytymisen muotoihin, supportiivisiin ilmauksiin ja supportiivisten sanomien kuvailuun. Tässä tutkimuksessa tuelle annetut merkitykset ovat sen kaltaisia, että niissä on helppo nähdä yhteyksiä näihin luokitteluihin. Aiemmat luokitukset ovat kuitenkin korostaneet juuri tuen antamista tavoitteellisena viestintäkäyttäytymisenä, kun taas tässä tutkimuksessa kuvatut merkitykset korostavat tuen ja viestintäkäyttäytymisen tulkitsemista.

Tutkija tuskin koskaan saavuttaa täysin sitä, mitä hän tutkimuksellaan tavoittelee. Tämä johtuu siitä, että tutkimusprosessin edetessä ymmärrys tutkittavasta ilmiöstä syvenee siten, että jo varsin pian mielessä alkaa herätä uusia kysymyksiä. Näin on käynyt tässäkin prosessissa. Vaikka aineistoani ei voi pitää valtavan suurena, hyvin rikkaaksi se on osoittautunut. Tämä tarkoittaa sitä, että mitä tahansa juonnetta voisi edelleen ja pitääkin edelleen syventää. Tämän tutkimuksen tarkoitukse- 
na oli etsiä yhteyksiä osastohoidon kontekstin, potilas-hoitajasuhteen ja sosiaalisen tuen välille. Olen mielestäni pystynyt näitä yhteyksiä osoittamaan, mutta tiedän, että näiden yhteyksien tarkasteleminen on vasta alkuvaiheessaan. Tutkijaksi kasvaminen merkitsee myös monenlaisten totuuteen ja tietoon liittyvien oletusten pohtimista ja kyseenalaistamista. Omassa prosessissani tietyt ajatukset ovat vahvistuneet, ja samalla ne ovat vaikuttaneet myös tutkimusprosessiin liittyvien valintojen tekemiseen. Tämä saattaa heijastua menetelmän koherenssiin, mutta toisaalta koen niiden myös syventäneen ymmärrystä tutkittavasta ilmiöstä.

Haasteensa tutkimukselle on antanut myös sosiaalisen tuen ilmiö itsessään ja varsinkin sen tarkasteleminen hoitotyön kontekstissa. Tutkiessaan sosiaalista tukea liikkuu väistämättä eri tieteenalojen rajapinnoilla, koska tutkimuksen kohteena olevaa ilmiötä on tutkittu useista näkökulmista. Tällöin mielestäni oleellista on, että tutkijalla on vahva oman alansa identiteetti samalla, kun hänellä on riittävän kattava kuva tuen tutkimisesta lähitieteissä. Tämän kuvan tarkkuutta on syytä pohtia kriittisesti, joskin olen pyrkinyt vastaamaan haasteeseen kiinnittymällä ennen muuta puheviestinnän teoriaan ja puheviestinnän tapaan jäsentää sosiaalisen tuen ilmiötä.

Empiirisen tutkimuksen tulokset keskustelevat tieteenalojen yli, ja tutkimukseni lähtökohtana ovat olleet erityisesti hoitotieteestä nousseet kiinnostavat kysymykset tyytyväisyydestä saatuun tukeen. Olen kuitenkin yrittänyt pitäytyä tulkinnoissa, jotka selittävät tukea viestintäprosessina. Puheviestinnän näkökulma näkyy tässä tutkimuksessa erityisesti käsitevalinnoissa sekä siinä, millä tavalla vuorovaikutussuhteen ja tuen ilmiöitä tarkastellaan. Näen myös, että puheviestinnän anti sosiaalisen tuen tutkimiselle on siinä, millä tavalla se antaa välineitä tuen käsitteellistämiseen ja tuen ymmärtämiseen viestintäprosessina, jossa rakennetaan sanoja ja luodaan merkityksiä.

Totesin puheenvuoroni aluksi, että vuorovaikutusta voidaan pitää ihmisenä olemisen peruskysymyksenä. Olennaista ihmisenä olemiselle 
on myös kyky kokea ja antaa merkityksiä omille kokemuksille. Näen, että tietoisuus merkitysten monimuotoisuudesta auttaa meitä ymmärtämään, miksi hyvät aikomuksemme eivät aina toteudu ja miksi motivaatio osoittaa tukea vuorovaikutuskumppanille ei aina tuota positiivisia tulkintoja. Emme aina saavuta niitä viestintätavoitteita, joita meillä on. Vuorovaikutusprosessien ymmärtäminen antaa meille kuitenkin välineitä entistä paremman yhteisymmärryksen tavoittelemiseen. Samalla se antaa myös välineitä supportiiviselle vuorovaikutukselle, joka edistää yksilön hyvinvointia ylläpitämällä käsitystä elämänhallinnasta ja hyväksytyksi tulemisesta.

Toisaalta on muistettava, että kaikkea ei voi palauttaa vuorovaikutukseen, vaikka puheviestinnän tutkijana mielellään niin tekisikin. Tässä tutkimuksessa nousi ilmi se, että hoitotyön organisoimiseen ja osastohoidon toteuttamiseen liittyy paljon haasteita, jotka itsessään vaikeuttavat potilaan ja hoitajan vuorovaikutussuhteen rakentumista ja jotka heijastuvat kokemukseen niin hoidosta kuin siinä toteutuvasta tuestakin. Nämä kysymykset ovat toki viestinnällisiä siinä mielessä, että ne perustuvat yhteiseen päätöksentekoon ja toiminnan organisoimiseen, mutta niiden taustalla on aina kysymys myös resursseista. Haluankin muistuttaa, että osastohoidon kontekstin ohella yhteiskunnallisella kontekstilla on merkitystä sille, kuinka tuki toteutuu. Me kaikki vuorovaikutuksessa toistemme kanssa olemme päättämässä siitä, millaiset ovat lähtökohdat tuen toteutumiselle potilas-hoitajasuhteessa. 